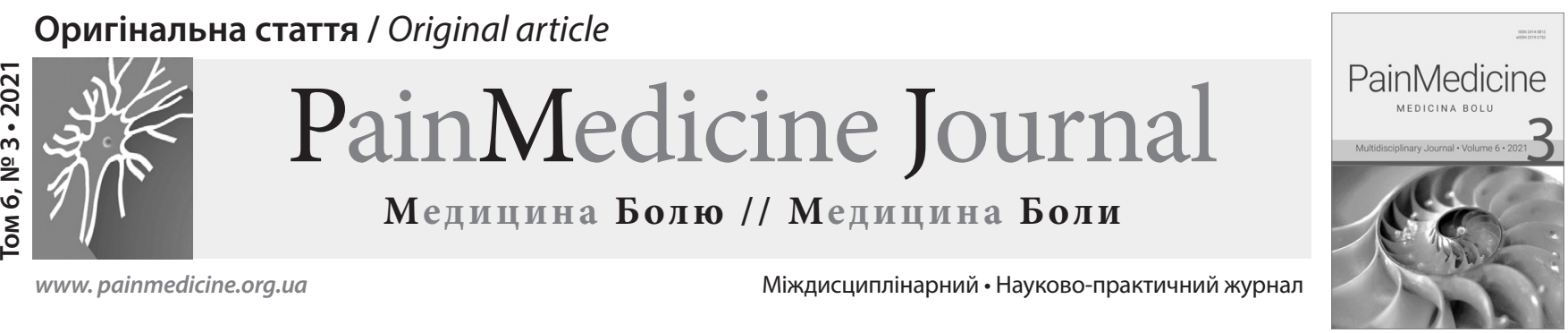

\title{
Continuous fentanyl infusion reduces intra-abdominal pressure, postoperative pain and normalizes lungs' mechanical changes in newborn with viscera-abdominal disproportion in early post-operative period
}

\author{
Konstantin Bercun ${ }^{1}$, Oleksandr Nazarchuk ${ }^{1,2}$, Oleksandr Dobrovanov ${ }^{3,4}$, Denis Surkov ${ }^{4}$, Viktor Vidiščák ${ }^{5}$ \\ ${ }^{1}$ National Pirogov Memorial Medical University, Vinnytsia, Ukraine \\ 2 Department of Anesthesiology and Intensive Care, Municipal non-profit enterprise "Vinnytsia Regional Clinical Hospi- \\ tal of Vinnytsia Regional Council", Vinnytsia, Ukraine \\ ${ }^{3}$ A. Getlik Clinic for Children and Adolescents of SMU and UHB, Bratislava, Slovakia \\ ${ }^{4}$ Regional Children Hospital, Neonatal Intensive Care Unit, Dnipro, Ukraine \\ ${ }^{5}$ Slovak Medical University, Bratislava, Slovakia
}

\begin{abstract}
We aimed to study the influence of prolonged administration of fentanyl on postoperative pain, intra-abdominal pressure and mechanical lungs' changes that may happen in neonates in early post-operative period. 30 newborns (in the period from January 2017 to May 2021) with gastroschisis were divided into two groups accordingly to the method of analgesia (14 - morphine hydrochloride; 16 - prolonged infusion of fentanyl). Lungs' mechanical characteristics, effectiveness of post-operative analgesia, abdominal wall relaxation was studied by monitoring of dynamic compliance $\left(C_{d y n}\right)$, pressure and flow-volume loops, capnography. Apprising analgesia status, we measured hemodynamic, $\mathrm{SaO}_{2}$, blood level of cortizol, $C$-reactive protein (CRP), glucose, analyzed postoperative pain syndrome using visual analogue scales (VAS). Intra-abdominal pressure (IAP) was controlled by Cron. For statistic analysis we used Student's t-test. In the group with morphine, thete was the increase of IAP by 11-12 $\mathrm{cm} \mathrm{H}_{2} \mathrm{O}$, being stable during some period of time, and also variable levels of pain according to VAS, the increasing of CRP from $0.8 \pm 0.25 \mathrm{mg} / \mathrm{dl}$ by $5 \mathrm{mg} / \mathrm{dl}$, cortisol by $674.4 \mathrm{nmol} / \mathrm{l}$, and blood glucosae rate $-7.4 \mathrm{mmol} / 1$. Periods with high traumatic effects and poor analgesia (morphine group) reasoned the increasing IAP, step by step dynamic compliance decreasing in 3.4 times, resistance increasing in 2.42 times and PIP rising till $22 \mathrm{~cm} \mathrm{H}_{2} \mathrm{O}$. Direct correlation between IAP increase and lungs' mechanical changes took place. The study has demonstrated that prolonged administration of fentanyl prevented high increase of IAP, CRP, levels of glucose and cortizol and changes of VAS data, lungs' mechanical characteristics.
\end{abstract}

Key words: fentanyl, gastroschisis, lungs function, newborns, postoperative pain. 


\section{Introduction}

Nowadays we have a great variety of analgetic drugs, but besides this $31 \%$ of children suffer of intensive peri-operative pain. Pain in peri-operative period is dangerous, but its influence on organ systems' functions such as lungs functioning and hemodynamic is of greater importance. In such a way pain may influence on oxygenation mechanisms in peri-operative period. Providing respiratory stability during peri-operative period in newborns with surgical problems is not an easy task, because they have at the same time not only surgical disease but some other neonates' lung functioning pathologies [1-3]. Peri-operative pain is the main barrier that influence on lung functional stability. The problem of how pain in neonates influences on lungs' mechanical characteristics have not been solved yet.

To study the influence of analgesia by means of prolonged fentanyl infusion on postoperative pain, intra-abdominal pressure and mechanical lungs' changes belonging to neonates in early post-operative period was the aim of our research work.

\section{Materials and methods}

Our study from January 2017 to May 2021 included 30 newborns who were operated because of congenital defects of front abdominal wall, such as gastroschisis. We divided all patients into two groups accordingly to the method of analgesia. In the first group (14 patients) we used for analgesia intravenous morphine hydrochloride every six hours in dose $-0.1-0.3 \mathrm{mg} / \mathrm{kg}$, In the second group (16 patients) we administered prolonged infusion of fentanyl solution in dose $3-5 \mathrm{mkg} / \mathrm{kg} / \mathrm{h}$. Such analgesia therapy continued during all periods of surgery and after the operation (5-7 days in general). The criteria to stop analgesia were respiratory stabilisation, spontaneous breathing recommencing and general stabilization of neonate's status. Every of the newborns had being treated before the operation to stabilize and normalize blood circulation volume, hemodynamic parameters, optimize microcirculation, to provide basic-acid homeostasis by means of well-known traditional infusion therapy approaches. The duration of such a therapy was about $24.8 \pm 7.5$ hours in patients having gastroschisis. Intra-operative volume was $23.4 \pm 10.0 \mathrm{ml} / \mathrm{kg} / \mathrm{h}$. The narcosis was: natrii oxybutyras $20 \%$ in dose 100 $150 \mathrm{mg} / \mathrm{kg}$ with fentanyl $0.005 \%$ in dose $20 \mu \mathrm{g} / \mathrm{kg}$. Lung ventilation was obligatory, using "Bear Cub" ventilator (A/C, SIMV/PSV), with tidal volume $-4-6 \mathrm{ml} / \mathrm{kg}$, PEEP $5 \mathrm{~cm} \mathrm{H}_{2} \mathrm{O}$, PIP $-12-22 \mathrm{~cm} \mathrm{H}_{2} \mathrm{O} \mathrm{Br}-30-35$ per minute. Ventilation was definitely dependent on defect value and data of intra-abdominal pressure increase. We studied lungs' mechanical characteristics' interdependency with effectiveness of post-operative analgesia and abdominal wall relaxation in the way of continuous monitoring of dynamic compliance $\left(\mathrm{C}_{\mathrm{dyn}}\right)$, pressure-volume and flow-volume loops, capnography by means of graphical monitor. The duration time of ventilation was $8.3 \pm 2.4$ days. Other methods to apprise the analgesia status we used were measurements of hemodynamic, $\mathrm{SaO}_{2}$, blood level of cortizol (by the way of immune-enzymatic analysis). For objective analysis of operative stress we measured serum levels of C-reactive protein (CRP) and glucose blood levels using standard methods [4, 5]. We measured blood levels of CRP, cortizol and glucose five times (1 hour before the operation and on the $1^{\text {st }}, 6^{\text {th }}, 12^{\text {th }}, 24^{\text {th }}$ hours after the operation). All laboratory studies were conducted in the clinical laboratory at Vinnytsia children's regional hospital. We held the subjective analysis of postoperative pain syndrome by the way of using visual analogue scales (VAS) Wang/Baker. To study the appearance of compartment-syndrome in neonates we used to measure intra-abdominal pressure (IAP) by Cron and Iberty [6]. Our study was held including some steps. They were: the $1^{\text {st }}$ step -1 hour after the operation, $2^{\text {nd }}$ step -6 hours, $3^{\text {rd }}$ step -12 hours, $4^{\text {th }}$ step -24 hours, $5^{\text {th }}$ step -36 hours after the operation.

To determine normal value of IAP, the same measurement had been conducted in 50 term and 50 preterm neonates who had no disorder of the abdomen. The results received in this patients group were considered as normal ones, they were: $8.92 \pm 0.18 \mathrm{~mm} \mathrm{Hg}$ (in term infants) and $7.84 \pm 0.12$ (in preterm infants).

For statistic analysis we used Student's t-test for conducting of parametric and nonparametric data.

Table 1. Demographic characteristics of the studied population

\begin{tabular}{lll}
\hline \multicolumn{1}{c}{ Total patients } & \multicolumn{1}{c}{$\begin{array}{c}\text { Gastroschisis } \\
\text { episodes }\end{array}$} & $\begin{array}{c}\text { Omphalocele } \\
\text { episodes }\end{array}$ \\
\hline Total episodes & 42 & 15 \\
\hline Birth weight (g)* & $1882.4 \pm 223.3$ & $2122.7 \pm 310.2$ \\
\hline Gestational age (weeks)* & $30.4 \pm 4.2$ & $31.2 \pm 3.4$ \\
\hline Male/female & $27 / 15$ & $7 / 8$ \\
\hline
\end{tabular}

Footnotes: * Mean 6 standard deviation (range).

Source: Authors' own processing.

Parents of all patients were informed about our research work and we got their permission to perform this study. Our study was carried out according to WMA Declaration of Helsinki - "Ethical Principles for Medical Research involving Human Subjects". We also followed the statements of Geneva Declaration of WMA. All statements of our experiment had been checked out by Ethical Committee and we got institutional review board approval. 


\section{Results and discussion}

The $1^{\text {st }}$ and $2^{\text {nd }}$ neonate groups were similar by sex-dimorphism, gestation terms and middle age. The research showed IAP increasing at first steps of the study (Table 1). Clear correlation between IAP changes, during different periods of research work, and changes of mechanical respiratory characteristics in neonates should be mentioned (Table 1). We have noticed that in the group where morphine was used, increase of IAP by 11-12 $\mathrm{cm} \mathrm{H}_{2} \mathrm{O}$ took place. High IAP was stable in this group during some period of time and did not decrease lower 10-12 $\mathrm{cm} \mathrm{H}_{2} \mathrm{O}$. During this period, in morphine group, we also had variable levels of pain according to VAS. They changed from middle data at the time when IAP was low and when lungs' mechanics became better to high meanings (the more time from morphine injection passed). But prolonged administration of fentanyl had being prevented such a high increase of IAP its data were near normal ones, time of its returning to the point of departure was shorten in comparison with those in the group with morphine. In fentanyl group data of VAS were almost constant. Such tendency we explain by the phenomenon of inadequate analgetic effect that take place when bolus morphine is used. It is proved by the increasing of CRP from the meaning of $0.8 \pm 0.25 \mathrm{mg} / \mathrm{dl}$ by $5 \mathrm{mg} / \mathrm{dl}$, cortisol by the meaning of $674.4 \mathrm{nmol} / \mathrm{l}$ and blood glucosae rate $-7.4 \mathrm{mmol} / \mathrm{l}$. During the operation there were some periods when IAP increase happened. These periods accompanying with high traumatic effects were the main reason of increased IAP. This can be explained as a result of poor analgesia because of low morphine dose (according to well-known pharmacokinetics of Morphni Hydrochloridi). Glucosae and cortizol levels were also high during these periods CRP increasing was accompanying too. IAP changes during different steps of the research directly influence on respiratory indices and breathing mechanics in newborns (Table 2). When operation trauma happens at the very beginning of surgical correction (when abdominal organs were plunging inside the reduced abdominal cavity and starting multivectorial gradual distraction of all front abdominal wall layers) we found step by step dynamic compliance decreasing in 3.4 times, resistance increasing in 2.42 times and PIP rising till $22 \mathrm{~cm} \mathrm{H}_{2} \mathrm{O}$ and maximum changes in graphical monitor in comparison

Table 2. Index changes during different steps of the viscera-abdominal correction study in newborns $(\mathrm{M} \pm \mathrm{m})$

\begin{tabular}{|c|c|c|c|c|c|}
\hline Index & $\begin{array}{l}\text { before the } \\
\text { operation }\end{array}$ & $\begin{array}{c}\text { 1st hour after } \\
\text { operation }\end{array}$ & $\begin{array}{l}\text { 6th hour after } \\
\text { operation }\end{array}$ & $\begin{array}{l}\text { 12th hour after } \\
\text { operation }\end{array}$ & $\begin{array}{c}24 \text { th hour } \\
\text { after operation }\end{array}$ \\
\hline \multicolumn{6}{|c|}{ Morphine $(n=14)$} \\
\hline $\mathrm{C}_{\mathrm{dyn}}\left(\mathrm{ml} / \mathrm{cm} \mathrm{H}_{2} \mathrm{O}\right)$ & $3.81 \pm 0.2$ & $1.12 \pm 0.1^{*}$ & $1.38 \pm 0.3^{*}$ & $2.23 \pm 0.1^{*}$ & $4.01 \pm 0.2$ \\
\hline $\operatorname{Rpk}\left(\mathrm{cm} \mathrm{H}_{2} \mathrm{O} / \mathrm{l} / \mathrm{kg}\right)$ & $189.0 \pm 9.01$ & $401.0 \pm 9.0^{*}$ & $280.0 \pm 9.1^{*}$ & $202.0 \pm 7.4^{*}$ & $198.0 \pm 8.0$ \\
\hline $\operatorname{PIP}\left(\mathrm{cm} \mathrm{H}_{2} \mathrm{O}\right)$ & $12.4 \pm 1.8$ & $14.6 \pm 2.4^{*}$ & $21.2 \pm 2.2^{*}$ & $18.6 \pm 1.9^{*}$ & $14.0 \pm 2.0$ \\
\hline IAP (mm Hg) & $8.5 \pm 0.22$ & $9.71 \pm 0.18^{*}$ & $11.0 \pm 0.31^{*}$ & $10.14 \pm 0.4^{*}$ & $8.57 \pm 0.2$ \\
\hline Glucosae $(\mathrm{mmol} / \mathrm{l})$ & $4.01 \pm 1.2$ & $6.01 \pm 1.1^{*}$ & $7.30 \pm 0.7^{*}$ & $7.2 \pm 0.5^{*}$ & $6.20 \pm 0.8$ \\
\hline Cortizoli (nmol/l) & $412.4 \pm 71.8$ & $622.4 \pm 82.4^{*}$ & $610.2 \pm 74.2^{*}$ & $588.4 \pm 71.0^{*}$ & $544.0 \pm 82.0$ \\
\hline C-protein (ml/dl) & $0.8 \pm 0.25$ & $1.3 \pm 0.2^{*}$ & $2.2 \pm 0.3^{*}$ & $3.8 \pm 0.2^{*}$ & $5.0 \pm 0.1$ \\
\hline \multicolumn{6}{|c|}{ Phentanyl infusion $(n=16)$} \\
\hline $\mathrm{C}_{\mathrm{dyn}}\left(\mathrm{ml} / \mathrm{cm} \mathrm{H}_{2} \mathrm{O}\right)$ & $4.01 \pm 0.1$ & $1.26 \pm 0.2^{*} \#$ & $1.48 \pm 0.2^{*} \#$ & $2.34 \pm 0.1^{*} \#$ & $3.99 \pm 0.2$ \\
\hline $\mathrm{Rpk}\left(\mathrm{cm} \mathrm{H}_{2} \mathrm{O} / \mathrm{l} / \mathrm{kg}\right)$ & $204.0 \pm 9.6$ & $472.0 \pm 9.0^{* \#}$ & $302.0 \pm 9.1 * \#$ & $212.0 \pm 8.2^{*} \#$ & $208.0 \pm 8.4$ \\
\hline PIP $\left(\mathrm{cm} \mathrm{H}_{2} \mathrm{O}\right)$ & $11.8 \pm 2.0$ & $14.0 \pm 1.9^{*} \#$ & $20.0 \pm 2.1^{* \#}$ & $17.4 \pm 2.2^{*} \#$ & $13.3 \pm 2.1$ \\
\hline IAP (mm Hg) & $8.71 \pm 0.29$ & $9.71 \pm 0.18^{* \#}$ & $10.33 \pm 0.33^{* \#}$ & $9.67 \pm 0.21^{* \#}$ & $8.33 \pm 0.21$ \\
\hline Glucosae $(\mathrm{mmol} / \mathrm{l})$ & $4.2 \pm 1.4$ & $5.3 \pm 0.4^{*} \#$ & $5.9 \pm 0.7^{* \#}$ & $5.2 \pm 0.4^{* \#}$ & $5.0 \pm 0.6$ \\
\hline Cortizoli (nmol/l) & $432.0 \pm 67.4$ & $499.2 \pm 91.0^{* \#}$ & $542.2 \pm 64.4^{* \#}$ & $580.0 \pm 74.4^{* \#}$ & $504.4 \pm 80.8$ \\
\hline C-protein & $0.8 \pm 0.3$ & $1.1 \pm 0.2^{*} \#$ & $1.3 \pm 0.25 * \#$ & $1.4 \pm 0.5^{*} \#$ & $1.0 \pm 0.2$ \\
\hline
\end{tabular}

Footnotes: $* \mathrm{p}<0.001$ in comparison with the first step examination (Student's t-test); $\#-\mathrm{p}<0.001$ in comparison with morphine group. Source: Authors' own processing. 
with those that were before the operation. IAP increased at the same time too (Table 2), (Fig. 1). In this research we found IAP increase in neonates having viscera-abdominal disproportion during all steps of anaesthesia.

There was direct correlation between IAP increase and lungs' mechanical changes (dynamic compliance decreasing in 3.5 times, airway resistance increasing in 2.4 times and PIP rising till $20.0 \pm 2.1 \mathrm{~cm} \mathrm{H}_{2} \mathrm{O}$ ) (Fig. 1).
Better analgesia we have attained by using prolonged administration of fentanyl that showed little changes in lungs' mechanical characteristics, insignificant increasing of CRP, slight levels of glucose and cortizol [7, 8] (Table 2, Fig. 2).

In conditions of surgical correction of viscera-abdominal disproportion in neonates it is very difficult to explain respiratory and hemodynamic changes. To realize this task we should take into account wide variety of
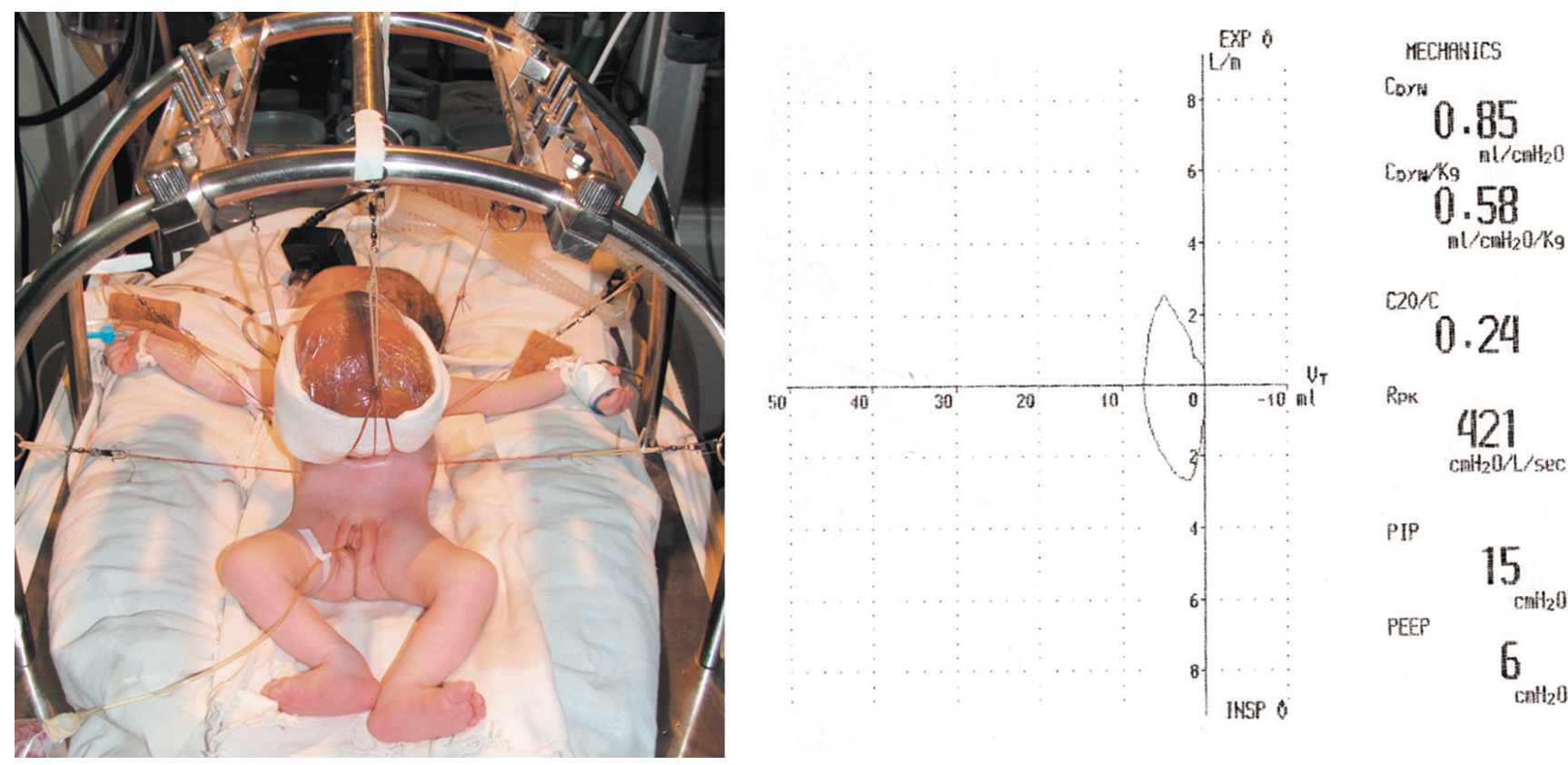

Fig. 1. The multivectorial distraction and graphical monitoring during the period of abdominal organs' plunging inside the reduced abdominal cavity (group with bolus administration of morphine hydrochloride).

Source: Authors' archive
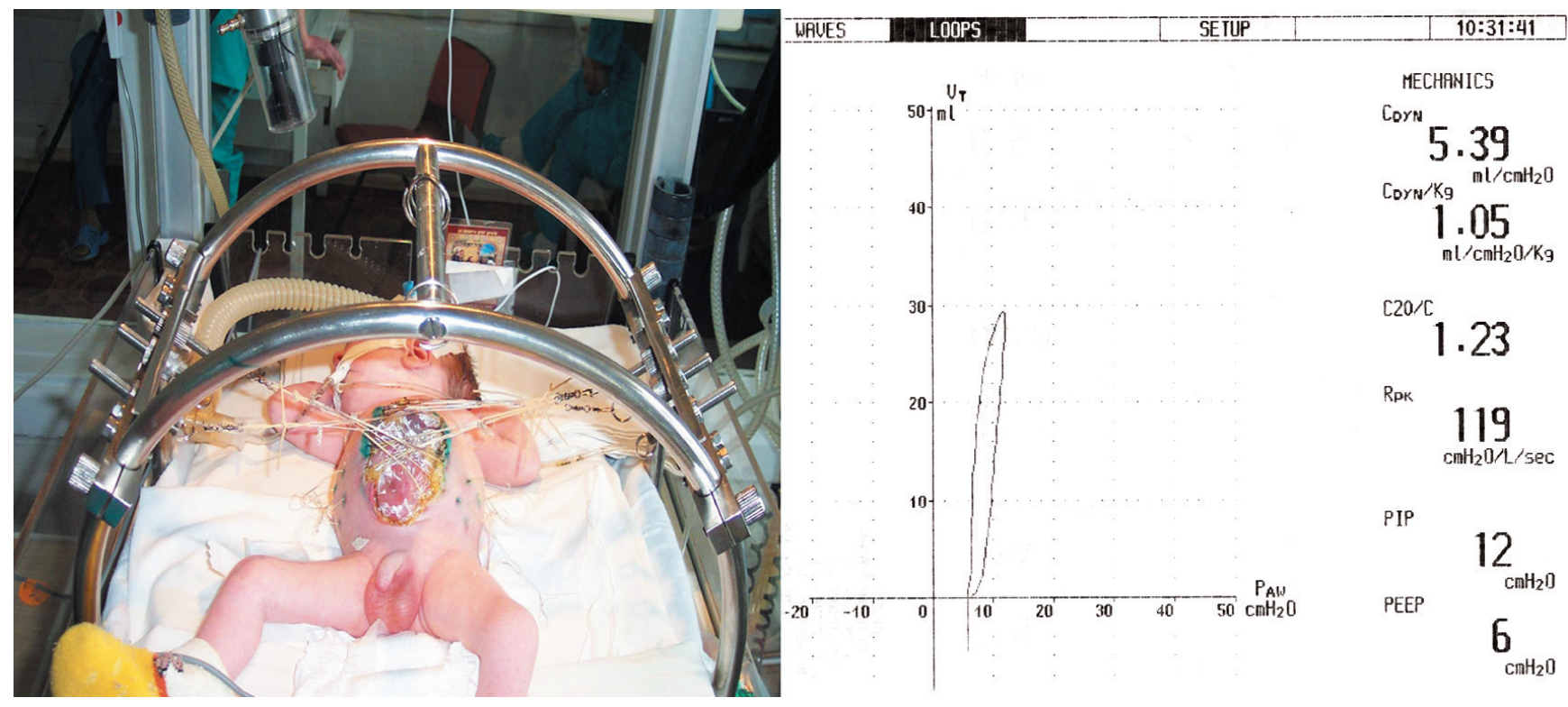

Fig. 2. The multivectorial distraction and graphical monitoring during the period of abdominal organs' plunging inside the reduced abdominal cavity (group with prolonged fentanyl administration).

Source: Authors' archive 
factors using complex study and differentiating analysis of pain origin in neonates. There is no indivisible reason provoking hemodynamic and lungs' mechanical changes mentioned earlier.

We suppose that during eventereted abdominal organs had being plunged into reduced abdominal cavity abdomen extended in volume and after that its tension happened. If neonate in such conditions had inadequate analgesia abdominal wall tension, increased IAP and receptors' irritation in tissues of abdominal walls that were being extended would decrease pain reception barrier of A- $\beta$ myelin nervous filaments (not nociception filaments). Centrifugal reflex arc of IAP increase is formed. They say that decrease of spatial discerntion because of more sensitive area of every nerve and wider area of their overlapping without modulation, very low barrier and enhanced transmition of nociception entrances in common lead to exaggerated pain answer in neonates [9].

In our study we found that bolus infusion of morphine did not guarantee adequate analgesia, which resulted in pain syndrome inducing the IAP increase during plunging organs into abdominal cavity. It is very important because IAP increases on definite steps of surgical correction of viscera-abdominal disproportion, and also, is dependent on such mechanical processes, as lack of adaptation to the abdominal wall tissue extension and insufficient abdominal cavity. High IAP increase leads to diaphragmatic displacement nearer to thorax resulting in increase of thorax pressure, lungs' volume decrease during expiration phase, decrease of lungs' functional residual capacity, decreasing inspiration lung volume, compression of lungs parenchyma that leads to alveolar collaboration in the base part of lungs, alveolar atelectasis and their damage (Fig. 1). World scientific data prove the same [10-12]. These conditions of lungs' functioning in neonates having viscera-abdominal disproportion make us think about ways of optimization patients' state of health and provide comfortable treatment to aim postoperative recovery of newborns in a short period of time. That is why we should provide adequate peri-operative analgesia because of pain syndrome's high stress effect (Fig. 2). Sufficient treatment of pain syndrome during all steps is a direct and successful way to optimize lungs' mechanics, to conduct mechanical ventilation in a proper way with functional respiratory stability.

\section{Conclusion}

When surgical correction of viscera-abdominal disproportion by the way of multivectorial extension in newborns is conducted we have IAP increase (mainly on the first 24-48 hours). We also, register direct correlation between high IAP and mechanical lungs' changes.

To provide adequate analgesia in peri-operative period is better to give prolongation infusion of fentanyl, be- cause it results in stability of IAP, prevents impulsation of pain, decreases intra-abdominal hypertensive mechanisms, gives the possibility to lungs function in physiological conditions. But morphine bolus administration gave only short therapeutic effect with progressively stable IAP increase leading to deterioration lungs' biomechanics and problems with adequate mechanical ventilation.

\section{Conflict of Interests}

None declared.

\section{References}

1. Jöhr M. Postoperative pain management in infants and children: new developments. Current Opinion in Anaesthesiology [Internet]. Ovid Technologies (Wolters Kluwer Health); 2000 Jun;13(3):285-9. Available from: https://doi. org/10.1097/00001503-200006000-00009

2. Malbrain MLNG. Abdominal pressure in the critically ill. Current Opinion in Critical Care [Internet]. Ovid Technologies (Wolters Kluwer Health); 2000 Feb;6(1):17-29. Available from: https://doi.org/10.1097/00075198-20000200000003

3. Malbrain ML. The role of abdominal distention in the search for optimal peep in acute lung injury (ALI). Critical Care Medicine [Internet]. Ovid Technologies (Wolters Kluwer Health); 1999 Jan;27(Supplement):157A. Available from: https://doi.org/10.1097/00003246-199901001-00458

4. Clark RH, Slutsky AS, Gerstmann DR. Lung Protective Strategies of Ventilation in the Neonate: What Are They? Pediatrics [Internet]. American Academy of Pediatrics (AAP); 2000 Jan 1;105(1):112-4. Available from: https://doi. org/10.1542/peds.105.1.112

5. Obeid F. Increases in Intra-abdominal Pressure Affect Pulmonary Compliance. Archives of Surgery [Internet]. American Medical Association (AMA); 1995 May 1;130(5):544. Available from: https://doi.org/10.1001/archsurg.1995.01430050094016

6. Kokhno VN, Shmerko PS, IIu S. Impact of preemptive analgesia on postoperative pain syndrome in laparoscopic surgery. Anesteziologiia i reanimatologiia. 2009 Nov 1(6):68-70.

7. OVERHOLT RH. Intraperitoneal pressure. Archives of Surgery [Internet]. American Medical Association (AMA); 1931 May 1;22(5):691. Available from: https://doi.org/10.1001/ archsurg.1931.01160050002001

8. Shaprynskyi V, Nazarchuk O, Faustova M, Mitiuk B, Dmytriiev D, Dobrovanov O, Kralinsky K, Babina Y. Some aspects of infectious complications in patients with surgical diseases. Multycentr trials. Lek. Obzor 2020;69(7-8):257-260.

9. Dmitriev DV, Dobrovanov AE, Kralinsky K, Babela R. Adaptive supportive ventilation in a child with coronavirus pneumonia and diabetes mellitus. Rossiyskiy Vestnik Perinatologii i Pediatrii (Russian Bulletin of Perinatology and Pediatrics) [Internet]. The National Academy of Pediatric Science and Innovation; 2020 Nov 22;65(5):66-72. Available from: https://doi.org/10.21508/1027-4065-2020-65-5-66-72

10. DMYTRIIEV D, DOBROVANOV O, KRALINSKY K, DMYTRIIEV K, MELNYChENKO M. A case report of successful experience of using adaptive support ventilation in the 
pediatric patient with viral interstitial pneumonia covid-19 positive. Lekarsky Obzor. 2021:119-23.

11. Lisnyy I, Zakalska O, Dmytriiev D, Dmytriiev K, Dobrovanov O. Pre-emptive analgesia with nonsteroidal anti-inflammatory drugs. Randomized, double-blind placebo-controlled study. Lek. Obzor 2021;70(5):195-202.

Континуальная инфузия фентанила снижает внутрибрюшное давление, послеоперационную боль и нормализует механические изменения легких у новорожденных с внутриабдоминальной диспропорцией в раннем послеоперационном периоде

Бериун K. ${ }^{1}$, Назарчук A. ${ }^{1,2}$, Доброванов А. ${ }^{3,4}$, Сурков Д. ${ }^{4}$, Видищак $B{ }^{5}$

${ }^{1}$ Нацииональныймедициинский университет им. Н.И.Пирогова, Винницза, Украина

${ }^{2}$ Отделение анестезиологии и реанимации, КНП "ВОКБ им. Н. И. Пирогова", Виннициа, Украина

${ }^{3}$ Клиника детей и подростков А. Гетлика, Словацикий медициинский университет, Братислава, Словакия

${ }^{4}$ Областная детская больница, отделение интенсивной терапии новорожденных, Днепр, Украина

${ }^{5}$ Словацкий медициннкий университет, Братислава, Словакия

Резюме. В исследовании изучается влияние континуальной инфузии фентанила на послеоперацционную боль, внутрибрюшное давление и механические изменения в легких, которые могут возникнуть у новорожденных в раннем послеоперационном периоде. По методу обезболивания 30 новорожденных (январь 2017 май 2021 г.) с гастрошизисом были разделены на две группы (14-ти был назначен морфина гидрохлорид; 16-ти - континуальная инфузия фентанила). Механические характеристики легких, эффективность послеоперациинной анальгезии, релаксациии брюшной стенки изучались путем мониторинга динамического комплайенса, петель давления и потока-объема, капнографии. Для оцзенки качества обезболивания измерялись параметры гемодинамики, сатурация кислорода в крови, уровень кортизола, С-реактивного белка, глюкозы, проводилась оценка послеоперационного болевого синдрома с помощью визуальных аналоговых шкал. Внутрибрюшное давление (IАР) контролировалось при помощи Cron. Для статистического анализа использовался t-критерий Стьюдента. В группе пациентов, получавших морфин, отмечалось увеличение ІАР на 11$12 \mathrm{~cm} \mathrm{H}_{2} \mathrm{O}$, уровня кортизола и глюкозы в крови. Эти эффекты были связаны с травматичностью операции и недостаточной анальгезией, что стало причиной увеличения IAP, постепенного снижения динамического комплайенса, увеличения резистентности легких. Отмечается прямая корреляциия между увеличением ІАР и механическими изменениями в легких. Исследование показало, что применение континуальной инфузии фентанила предотвращает все вышеперечисленные нежелательные эффекты.

Ключевые слова: фентанил, гастрошизис, функциия легких, новорожденные, послеоперациионная боль
12. Kovalchuk VP, Nazarchuk OA, Burkot VM, Fomina NS, Prokopchuk ZM, Dobrovanov O. Biofilm forming activity of non-fermenting gram-negative bacteria. Wiadomości Lekarskie [Internet]. ALUNA; 2021;74(2):252-6. Available from: https://doi.org/10.36740/wlek202102114

Безперервна інфузія фентанілу знижує внутрішньочеревний тиск, післяопераційний біль і нормалізує механічні зміни у легенях новонароджених 3 внутрішньоабдомінальною диспропорцією у ранньому післяопераційному періоді

Бериун K. ${ }^{1}$, Назарчук O. ${ }^{1,2}$, Доброванов A. ${ }^{3,4}$, Сурков Д. ${ }^{4}$, Biдіщак $B .{ }^{5}$

${ }^{1}$ Національний медичний університет ім. М. І. Пирогова, Вінницяя, Україна

${ }^{2}$ Відділення анестезіології та реанімації, КНП “ВОКЛ ім. М. І. Пирогова ВОР”, Вінницяя, Україна

${ }^{3}$ Клініка дітей і підлітків А. Гетліка, Словацький медичний університет, Братислава, Словаччина

${ }^{4}$ Обласна дитяча лікарня, відділення інтенсивної терапії новонароджених, Дніпро, Україна

${ }^{5}$ Словацький медичний університет, Братислава, Словаччина

Резюме. У дослідженні вивчається вплив континуальної інфузії фентанілу на післяопераційний біль, внутрішньочеревний тиск і механічні зміни в легенях, які можуть виникнути у новонароджених у ранньому післяопераційному періоді. За методом знеболення 30 новонароджених (січень 2017 - травень 2021 г.) $з$ гастрошизисом були розділені на дві групи (14-ти було призначено морфіну гідрохлорид; 16-ти - континуальна інфузія фентанілу). Механічні характеристики легень, ефективність післяопераційної аналгезії, релаксації черевної стінки вивчалися шляхом моніторингу динамічного комплаєнсу, петель тиску і петель потоку-об'єму, капнографії. Для оцінки якості знеболювання вимірювалися параметри гемодинаміки, сатурація кисню в крові, рівень кортизолу, С-реактивного білка, глюкози, проводилася оцінка післяоперациійного больового синдрому за допомогою візуальних аналогових шкал. Внутрішньочеревний тиск (IAP) контролювався за допомогою Cron. Для статистичного аналізу використовувався t-критерій Стьюдента. У групі пацієнтів, які отримували морфін, відзначалося збільшення IAP на 11-12 см $\mathrm{H}_{2} \mathrm{O}$, рівня кортизолу та глюкози в крові. Ці ефекти були пов'язані з травматичністю операції і недостатньою анальгезією, що стало причиною збільшення IAP, поступового зниження динамічного комплаєнсу, підвищення резистентності легень. Відзначається пряма кореляція між збільшенням IАР та механічними змінами в легенях. Дослідження показало, ще застосування континуальної інфузії фентанілу запобігає всім перерахованим вище небажаним ефектам.

Ключові слова: фентаніл, гастрошизис, функція легень, новонароджений, післяопераційний біль 